\title{
Habitat Selection and Activity Pattern of GPS Collared Sumateran Tigers
}

\author{
Dolly Priatna $^{1 *}$, Yanto Santosa ${ }^{2}$, Lilik Budi Prasetyo $^{2}$, Agus Priyono Kartono ${ }^{2}$ \\ 'Graduate School of Bogor Agricultural University, Dramaga Main Road, Campus IPB Dramaga, Bogor 16680, Indonesia \\ ${ }^{2}$ Department of Forest Resources Conservation \& Ecotourism, Faculty of Forestry, Bogor Agricultural University, \\ Academic Ring Road, Campus IPB Dramaga, PO Box 168, Bogor 16680, Indonesia
}

Received May 22, 2012/Accepted June 18, 2012

\begin{abstract}
Although translocation has been used in mitigating human-carnivore conflict for decades, few studies have been conducted on the behavioral ecology of released animals. Such information is necessary in the context of sustainable forest management. In this study we determine the type of land cover used as main habitat and examine the activity pattern of translocated tigers. Between 2008 and 2010 we captured six conflict tigers and translocated them 74$1,350 \mathrm{~km}$ from their capture sites in Sumatera. All tigers were fitted with global positioning system (GPS) collars. The collars were set to fix 24-48 location coordinates per day. All translocated tigers showed a preference for a certain habitat type within their new home range, and tended to select the majority of natural land cover type within the landscape as their main habitat, but the availability of natural forest habitat within the landscape remains essensial for their survival. The activity of male translocated tigers differed significantly between the six time intervals of 24 hours, and their most active periods were in the afternoon (14:00-18:00 hours) and in the evening (18:00-22:00 hours). Despite being preliminary, the findings of this study-which was the first such study conducted in Sumaterahighlight the conservation value of tiger translocation and provide valuable information for improving future management of conflict tigers.
\end{abstract}

Keywords: activity pattern, GPS collars, habitat selection, sumateran tiger, translocation

*Correspondence author,email:dolly.priatna@gmail.com,telp.+62-813-8900-1566

\section{Introduction}

The sumateran tiger (Panthera tigris sumatrae Pocock, 1929 ) is the only subspecies of tiger still remaining in Indonesia, after 2 of its relatives, the bali tiger (P. t. balica) and the javan tiger ( $P$. t. sondaica) were declared extinct in the 1940s and 1980s, respectively (Seidensticker et al. 1999). Sumateran tigers are distributed all over the island of Sumatera, but they live in isolated populations (Wibisono \& Pusparini 2010). Most of them inhabit 12 Tiger Conservation Landscapes (TCL) whose total area is around $88,000 \mathrm{~km}^{2}$ (Sanderson et al. 2010). At present, sumateran tigers face many threats originating from human activities (Seidensticker 1986; Seidensticker et al. 1999), which causes conflict between humans and tigers (Nugraha \& Sugardjito 2009). In Sumatera, conflict between humans and tigers has become a major problem in tiger conservation, due to its effect in the form of loss of property and human life, which will ultimately decrease people's support for tiger conservation efforts. Such conflict is also one of the factors which triggers people to hunt and even kill tigers (Nugraha \& Sugardjito 2009).

In the last several decades, translocation has been one of the methods used for mitigating conflict between humans and wild animals, such as in the case of brown bears (Ursus arctos) and black bears (U. americama) (Armistead et al. 1994; Blanchard \& Knight 1995), wolves (Fritts et al. 1984; Bangs et al. 1999), and large cats (Rabinowitz 1986; Stander 1990; Ruth et al. 1998), including tigers (Seidensticker et al. 1976; Nowell \& Jackson 1996; Goodrich \& Miquelle 2005; Priatna et al. 2012). However, there is still little research being conducted on the ecology and behavior of wild animals after they are released again to the wild or after being translocated. Understanding the ecological requirements or prerequisites for this rare carnivorous wild animal is very important for implementing an effective management and conservation strategy (Grassman et al. 2005). Santosa \& Rahman (2012) explained that protection of wild animals which are umbrella species, such as the sumateran tiger, occupies a very important position in sustainable forest management, due to its implications for other species and its role in maintaining ecosystem stability.

Global positioning system collars (GPS device fitted around a wild animal's neck) are frequently used for the study of habitat selection and movement of wild animals (Edwards et al. 2001; Coelho et al. 2008) because the device is able to provide accurate information on a wild animal's location in various conditions (Hebblewhite et al. 2007). Habitat selection is a process whereby individual wild animals, in preferential manner, utilize the available habitats in a 
landscape (Morris 2003). Wild animal movement, besides being affected by environmental conditions, is also affected by the distribution of resources needed by the animal to grow, reproduce, and survive (Begon et al. 1986). Meanwhile, Valeix et al. (2010) explained that the spatial ecology and movement of a predator animal are very much affected by habitat characteristics which determine the distribution of its prey animals.

Studies related to the use of habitat and activity patterns of Felidae species have been conducted on snow leopards (Jackson 1996; Xu et al. 2012), as well as on clouded leopards, golden cats, marble cats (Grassman et al. 2005), and on asian leopards (Simcharoen et al. 2008). Similar research on wild tigers has been conducted in Nepal (Sunquist 1981) and in Sumatera (Sunarto et al. 2012). However, such studies have never been conducted on sumateran tigers which have been translocated, so the success rate of tiger translocation in Sumatera is difficult to measure. The objective of this research was to determine the vegetation cover type which was chosen as the main habitat by the tiger and to study the activity pattern of tranlocated sumateran tigers.

\section{Methods}

This research was conducted from July 2008 through August 2011 in four locations of tiger translocation in
Sumatera, i.e. Bukit Barisan Selatan National Park (BBSNP) in the Province of Lampung, southern Sumatera; Gunung Leuser National Park (GLNP) and Ulu Masen Ecosystem (UME) in the Province of Aceh, northern Sumatera; and Kerinci Seblat National Park (TNKS) in the Province of West Sumatera (Figure 1).

Between July 2008 and December 2010, we collaborated with the Directorate General of Forest Protection and Nature Conservation (PHKA), Ministry of Forestry, in handling human-tiger conflicts. After undergoing a recovery period of between 16 and 225 days in quarantine facilities, 6 sumateran tigers ( 5 males and 1 female) which conflicted with humans (entering villages and killing livestocks) were translocated to 4 different locations at distances of between 74 and 1,350 km from the places where each of them were captured. After all programmed to determine the duration of active period and the number of position data readings which would be fixed every day, GPS collars (Televilt, Lindesberg, Sweden; Argos/Sirtrack Ltd, Hawkes Bay, New Zealand) were fitted on the 6 tigers before they were released back to the wild. With the aid of satellite, tiger position data from the GPS collars were periodically transmitted to a server every day and were subsequently sent to an appointed email address.

In analysis of habitat utilization, all collected data from each GPS collar were screened to obtain tiger position data with high accuracy, i.e. those data which were fixed using 4 or

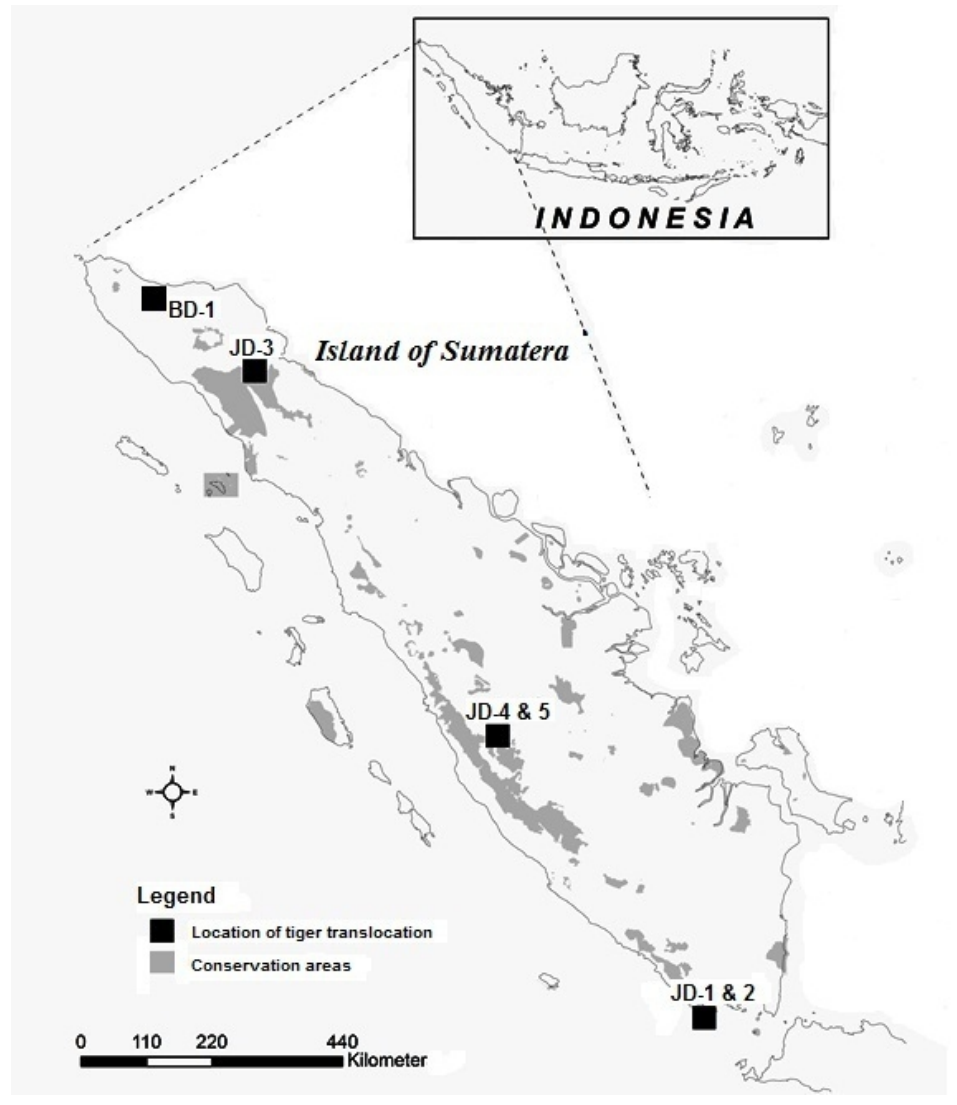

Data source: Directorate of Area Conservation and Protected Forest, PHKA (Indonesia's Ministry of Forestry) and results of field survey

Figure 1 Location of tiger translocation in 4 forest areas in Sumatera (JD-1 \& 2 in BBSNP, JD-3 in GLNP, JD-4 \& 5 in KSNP and BD-1 in UME). 
more satellites (Gamo et al. 2000). Using ArcGIS v.9.3 (ESRI, Redlands, California), the position data were overlaid with a land cover map (MODIS, Moderate Resolution Imaging Spectroradiometer, resolution of 250 meter, 2010) to determine the vegetation type which was used most frequently by the translocated tiger. According to Meittinen et al. (2012) this MODIS map possesses an accuracy level of up to $85 \%$. Besides providing position data, the GPS collars fitted on the 2 adult male tigers (JD-1 and JD-5) also provided information on their activities and movement. There were 2 signals which recorded the tigers' activities: signal X, which indicated that the GPS collar worn by the tiger moved vertically (forward and backward), and signal Y, which indicated that the GPS collar moved horizontally (to left and right). The pattern of tiger activities for 24 hours was divided into 6 time intervals, i.e. morning (06:00-09:59), noon time (10:00-13:59), late afternoon (14:00-17:59), evening/night (18:00-21:59), midnight (22:00-01:59), and dawn (02:0005:59).

The chi-square test (Zar 1996) was used to know whether each tiger individual had a preference for a particular habitat. If a preference was found, Neu's habitat suitability index was calculated (Bibby et al. 1988) to determine the most preferred vegetation type. To identify the difference in habitat utilization between day time and night time, the Wilcoxon signed rank test was used. The chi-square test and Neu index were also applied to identify the most active period of time for the tiger during a 24-hour period.

\section{Results and Discussion}

In total, 6 tigers were translocated and fitted with GPS collars during the research. However, 1 tiger which was translocated to TNKS (JD-4) was found dead only 7 days after released back to the wild, due to a snare trap set up by a serow poacher inside the park area. The movements of tigers JD-1 and JD-2, which were released in BBSNP, were observed for 224 days (generating 3,469 position data points) and 253 days (1,288 position data points), respectively. Tiger BD-1, which was translocated to UME and observed for 213 days (6,680 position data points), was found dead due to a snare trap on farmland at the edge of the forest, after its GPS collar worked for 7 months. The movement of tiger
JD-3 in GLNP was observed for 79 days (1,486 position data points), and tiger JD-5 in TNKS was monitored for 238 days (7,007 position data points). GPS collars which were fitted on tigers JD-1, JD-3, and JD-5 were damaged after operating for 7.5 months, 2.5 months, and 8 months, respectively. The GPS collar on JD-2 was detached automatically as planned, after operating for 8.5 months.

Selection of habitat The results of overlaying position data with a map of vegetation cover, and the chi-square test, showed that $\chi_{\text {calculated }}^{2}>\chi_{\text {table }}^{2}(0.05)$ for all tigers, which implies that all translocated tigers were proven significantly as having a preference for a particular habitat in each location where they were released (Table 1). Preference analysis using Neu method also confirmed that each translocated tiger selected a particular vegetation cover type as their main habitat.

Tigers JD-1 and JD-2, which were released in BBSNP, and tiger JD-5 in TNKS all utilized vegetation cover of plantation/regrowth (bush/young secondary forest) with very high intensity $(93.4,96.3$, and $58.6 \%$, respectively). This occurred because vegetation cover of bush/young secondary forest was dominant in the landscape where they were released (79.4\% in BBSNP and $41.6 \%$ in TNKS). However, those tigers also used lowland forest as habitat, which ranked second in terms of utilization intensity. Tiger JD-3, which was released in GLNP, combined the use of lower montane forest $(42.8 \%)$ and lowland forest $(30.1 \%)$ as its main habitat. This phenomenon also occurred because the 2 types of vegetation cover were in fact dominant in the landscape where JD-3 was translocated. Therefore, there was a tendency for each tiger to show a preference toward a particular type of habitat. However, this selection was also based on the natural habitat type which was dominant in the area where they were released (Figure 2). Besides that, it was also proven that the existence of natural forest within the landscape as habitat or cover remains important for tiger survival. Although Sunquist et al. (1999) suggested that globally, tigers inhabit various types of habitat and are able to adapt to various environmental conditions, Sunarto et al. (2012) have proven that tigers in Sumatera are very much dependent on and prefer natural forest area. According to them, tigers also use oil palm plantation and acacia forest, although in a very small

Table 1 Most preferred habitat types by translocated tigers in each release sites, with the values of chi-square test and Neu index (W)

\begin{tabular}{llll}
\hline Tiger & Location $^{*}$ & Results of chi-square test & Most preferred habitat (value of Neu index $/ \mathrm{W})$ \\
\hline JD-1 & BBSNP & $\begin{array}{l}\chi_{\text {calculated }}^{2}=304.04>\chi_{\text {table }}^{2} \\
(0.05 ; 5)=11.07\end{array}$ & Plantation/regrowth (bush/young secondary forest) $(\mathrm{W}=1.18)$ \\
JD-2 & BBSNP & $\begin{array}{l}\chi_{\text {calculated }}^{2}=2,840.72>\chi_{\text {table }}^{2} \\
(0.05 ; 5)=11.07\end{array}$ & Plantation/regrowth (bush/young secondary forest) $(\mathrm{W}=1.21)$ \\
& & $\begin{array}{l}\chi_{\text {calculated }}^{2}=306.96>\chi_{\text {table }}^{2} \\
(0.05 ; 8)=15.51\end{array}$ & Lower montane forest $(\mathrm{W}=1.41)$ \\
JD-3 & GLNP & $\begin{array}{l}\chi_{\text {calculated }}^{2}=3,551.99>\chi_{\text {table }}^{2} \\
(0.05 ; 9)=16.92\end{array}$ & Lowland forest $(\mathrm{W}=1.98)$ \\
& KSNP & $\begin{array}{l}\chi_{\text {calculated }}^{2}=3,234.16>\chi_{\text {table }}^{2} \\
(0.05 ; 6)=12.59\end{array}$ & Plantation/regrowth (bush/young secondary forest) $(\mathrm{W}=2.17)$ \\
\hline
\end{tabular}

* BBSNP: Bukit Barisan National Park; GLNP: Gunung Leuseur National Park; KSNP: Kerinci Seblat National Park; UME: Ulu Mansen Ecosystem 


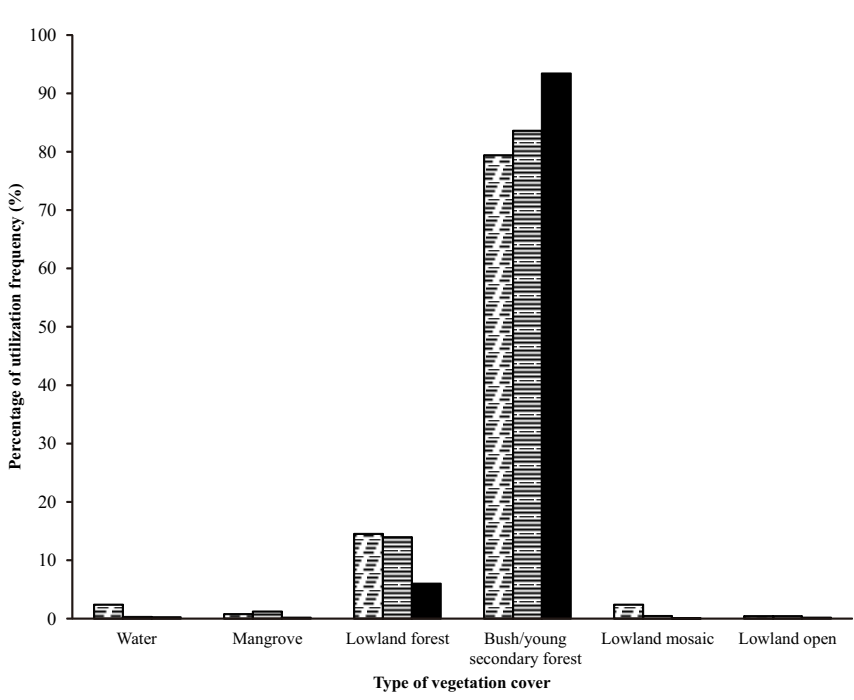

A Tiger JD-1
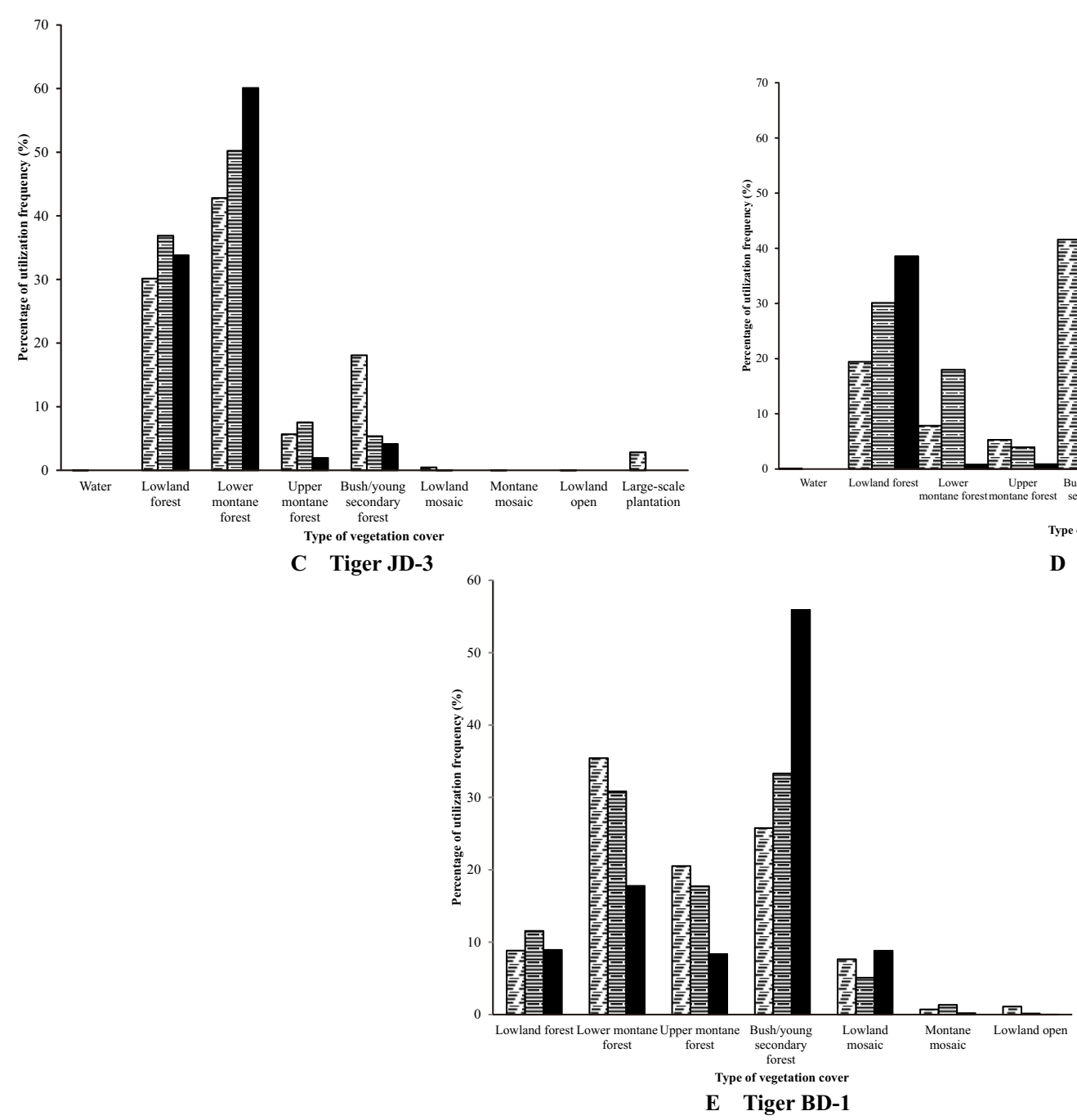

Figure 2 Percentage of vegetation cover types availability in each study sites and within the tiger home ranges as well as their utilization by each individual translocated tiger $(A=$ tiger JD-1, $B=$ tiger JD-2, $C=$ tiger JD-3, $D=$ tigerJD-5, $E=$ tiger $\mathrm{BD}-1)$. (国) \% size within study area, (曰) \% size within home range, $(\boldsymbol{\Xi}) \%$ utilition frequency $(\mathrm{N}), \mathrm{N}$ tiger JD-2 = 1.228 , $\mathrm{N}$ tiger JD-3 = 1.281, $\mathrm{N}$ tiger JD-5 = 5.996, $\mathrm{N}$ tiger BD-1 =6.116. 
Table 2 Percentage of habitat type/vegetation cover utilization by tigers in the day time (D) and night time (N) in each translocation sites

\begin{tabular}{|c|c|c|c|c|c|c|c|c|}
\hline \multirow{3}{*}{ Habitat type/vegetation cover } & \multicolumn{8}{|c|}{ Percentage of utilization frequency (\%) } \\
\hline & \multicolumn{2}{|c|}{$\begin{array}{l}\text { Tiger } \\
\text { JD-1 }\end{array}$} & \multicolumn{2}{|c|}{$\begin{array}{l}\text { Tiger } \\
\text { JD-3 }\end{array}$} & \multicolumn{2}{|c|}{$\begin{array}{l}\text { Tiger } \\
\text { JD-5 }\end{array}$} & \multicolumn{2}{|c|}{$\begin{array}{l}\text { Tiger } \\
\text { BD-1 }\end{array}$} \\
\hline & $\mathrm{D}$ & $\mathrm{N}$ & $\mathrm{D}$ & $\mathrm{N}$ & $\mathrm{D}$ & $\mathrm{N}$ & $\mathrm{D}$ & $\mathrm{N}$ \\
\hline Water & 0.0 & 0.4 & 0.0 & 0.0 & 0.0 & 0.0 & & \\
\hline Mangrove & 0.1 & 0.2 & & & & & & \\
\hline \multicolumn{9}{|l|}{ Peat swamp forest } \\
\hline Lowland forest & $\underline{6.4}$ & $\underline{5.7}$ & $\underline{32.2}$ & $\underline{35.2}$ & 43.9 & $\underline{34.2}$ & 9.2 & 8.7 \\
\hline Lower montane forest & & & $\underline{62.2}$ & $\underline{58.2}$ & 1.0 & 0.7 & $\underline{17.8}$ & $\underline{17.8}$ \\
\hline Upper montane forest & & & 2.0 & 1.9 & 0.6 & 1.1 & 7.5 & 9.2 \\
\hline $\begin{array}{l}\text { Plantation/regrowth (bush/young } \\
\text { secondary forest) }\end{array}$ & $\underline{93.6}$ & $\underline{93.3}$ & 3.6 & 4.6 & $\underline{54.1}$ & $\underline{62.3}$ & $\underline{56.7}$ & $\underline{55.1}$ \\
\hline Lowland mosaic & 0.0 & 0.1 & 0.0 & 0.0 & 0.1 & 0.7 & 8.7 & 8.9 \\
\hline Montane mosaic & & & 0.0 & 0.0 & 0.0 & 0.0 & 0.1 & 0.3 \\
\hline Lowland open & 0.0 & 0.3 & 0.0 & 0.0 & 0.0 & 0.0 & 0.0 & 0.0 \\
\hline Montane open & & & & & 0.3 & 0.0 & & \\
\hline \multicolumn{9}{|l|}{ Urban } \\
\hline Large-scale plantation & & & 0.0 & 0.0 & 0.0 & 1.0 & & \\
\hline Total $(\%)$ & 100 & 100 & 100 & 100 & 100 & 100 & 100 & 100 \\
\hline $\mathrm{N}$ position data & 1,351 & 1,601 & 608 & 673 & 2,679 & 3,287 & 2,949 & 3,167 \\
\hline
\end{tabular}

proportion as compared to the size of the available area. Our observations in the translocation area of TNKS support this statement, although oil palm plantation covered $18.5 \%$ of the landscape where the tiger was released in TNKS, tiger JD-5 spent only $0.6 \%$ of its time in oil palm plantation area. Maddox et al. (2007) explained that sumateran tigers often use bush land/young secondary forest in oil palm plantation areas, but they do not use area with monoculture oil palm. Sunarto (2011) explained that sumateran tigers were often detected in areas with thick undergrowth vegetation.

Utilization of day time and night time habitat Observation results showed slight variations for each translocated tiger in the use of each main habitat type in the day time and night time. Male tiger JD-1, which was translocated to BBSNP, used plantation/regrowth (bush/young secondary forest) habitat as much as $93.6 \%$ in the day time and $93.3 \%$ in the night time. Tiger JD-3 in GLNP spent $62.2 \%$ of its day time and $58.2 \%$ of its night time in lower montane forest habitat. Tiger JD-5 spent $54.1 \%$ of its day time and $62.3 \%$ of its night time in plantation/regrowth (bush/young secondary forest) habitat. Female tiger BD-1 spent $56.7 \%$ of its day time and $55.1 \%$ of its night time roaming in plantation/regrowth (bush/young secondary forest) habitat (Table 2). However, the results of the Wilcoxon signed rank test for each tiger individual showed that there was no significant difference between day time and night time in terms of habitat utilization (JD- $1: Z=-0.211 ; \mathrm{p}=$ $0.883>0.05, \mathrm{JD}-3: \mathrm{Z}=0.000 ; \mathrm{p}=1.000>0.05, \mathrm{JD}-5: \mathrm{Z}=$
$-0.315 ; \mathrm{p}=0.752>0.05$, and $\mathrm{BD}-1: \mathrm{Z}=-0.135 ; \mathrm{p}=0.892>$ $0.05)$. On the other hand, results by Simcharoen et al. (2008) showed that asian leopards in Thailand used various habitat types with differing proportion between day time and night time. This phenomenon is probably due to the existence of tigers which live sympatrically with asian leopards, where the asian leopard uses one type of habitat when the tiger does not use it.

Patterns of activity Results of data processing of tiger activity showed that signal $\mathrm{X}$ and signal $\mathrm{Y}$ gave the same results. This implies that if the tiger was moving, both signal $X$ and $\mathrm{Y}$ would indicate that the tiger was active. On the other hand, if the tiger was resting, both signals $\mathrm{X}$ and $\mathrm{Y}$ would indicate non activity. Male tiger JD-1 was detected as active in $1,483(42.8 \%)$ of the 3,469 detected data points, whereas male JD-5 was detected as active in 3,465 (49.5\%) of the 7,007 detected data points. Similar research results for other species of Felidae in Thailand revealed that male and female clouded leopards (Neofelis nebulosa) were active as much as $57 \%$ and $59 \%$, respectively, during the observation period (Grassman et al. 2005). This shows that tigers are more efficient in utilizing their activity time compared to clouded leopards. Our research results also show that male sumateran tigers, during night time (18:00-06:00 hours) used $45.5 \%$ of their time to be active and move. A similar phenomenon was observed for bengal tigers in Nepal, where they used $42 \%$ of their night time for conducting activities and movement (Sunquist 1981).

From the graphic pattern formed by signals $\mathrm{X}$ and $\mathrm{Y}$ (Figure 3), it can be seen that the 2 male tigers (JD-1 and JD-5) 


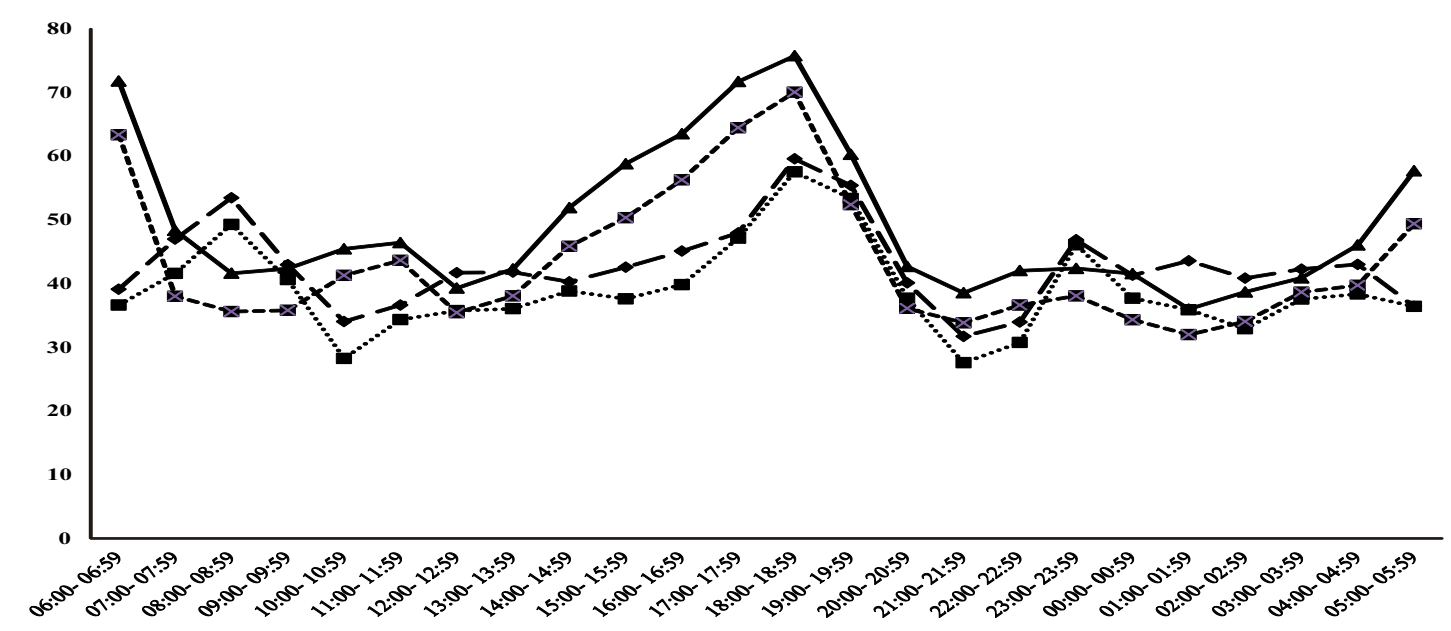

Figure 3 Activity patterns of translocated Sumatran tigers which were monitored using signal X and Y within GPS collars (total N data for Tiger JD-1= 1,599 and for Tiger JD-5=3,643). JD -1 Signal X(\%) (־), JD-1 Signal Y (\%) (-.), JD-5 Signal X(\%), $(\rightarrow)$, JD-5 Signal Y $(\%)(-)$.

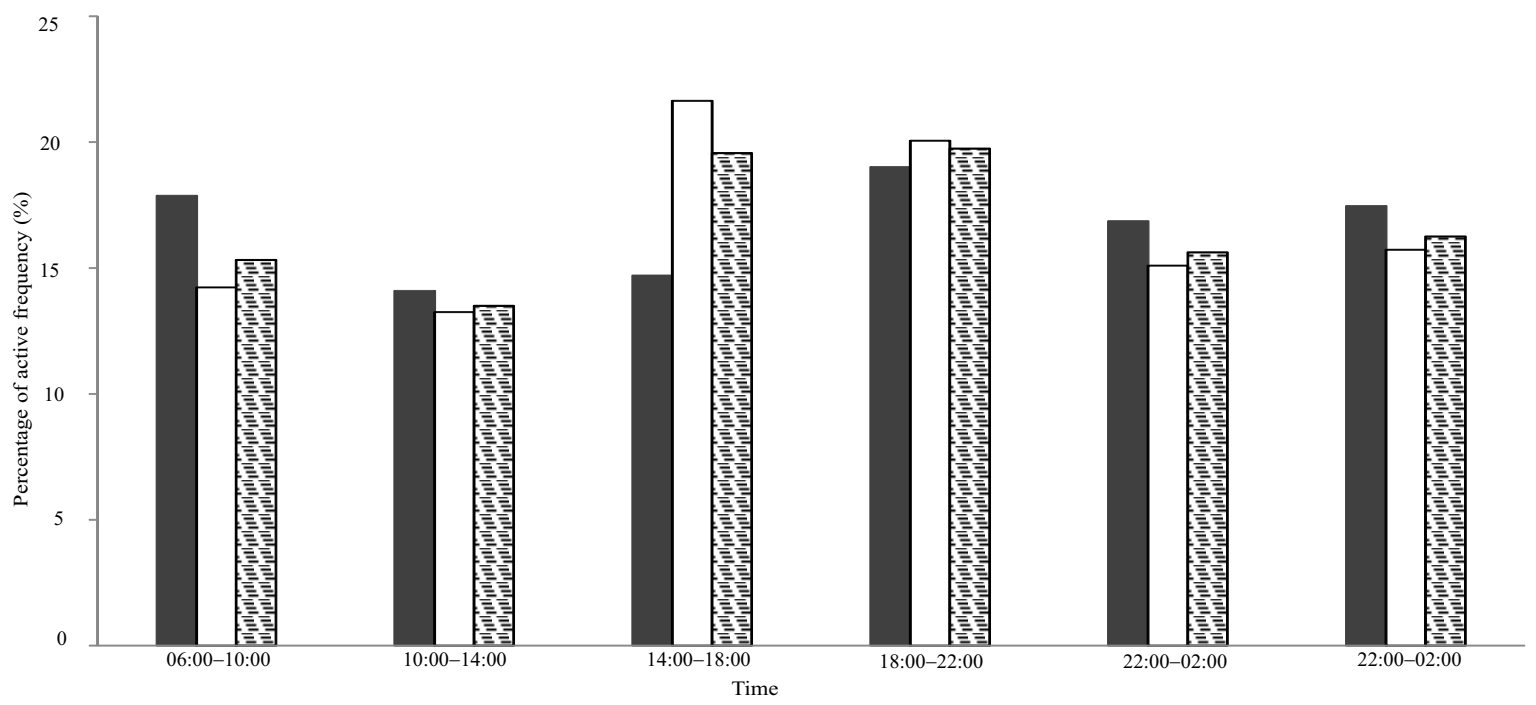

Figure 4 Graphic of 24 hours activity pattern of translocated sumateran tigers based on 4 hours interval. Tiger JD-1 ( $\square$ ), tiger JD-5 (口), all tigers (国).

conducted many movements and the most active time started at late afternoon before dark and proceeded into the night. However, male tiger JD-5 was also seen to conduct many activities at dawn before morning time, while tiger JD-1 was less active in the morning. The 2 tigers decreased their activities in the morning until noon time, and at midnight until before dawn.

Observation results show that for male tigers, the most active period was late afternoon (14:00-18:00 hours) and evening/night (18:00-22:00 hours). However, individually, there was a small difference for male tiger JD-1, which was translocated to BBSNP: its most active times were in the evening/night (18:00-22:00 hours) and in the morning (06:00-10:00 hours) (Figure 4). Through the chi-square test $\left(X_{\text {calculated }}^{2}=91.96>X_{\text {table }}^{2}(0.05 ; 5)=11.07\right)$, it can be concluded that within a period of 24 hours (one full day and night), there is significantly a most active period of time for the tiger. Neu analysis shows that the most active times, with the greatest number of movements, were the late afternoon (14:00-18:00 hours Western Indonesia Time/GMT +7$)(\mathrm{Neu}$ index $/ \mathrm{W}=$ 1.17) and evening/night time (18:00-22:00 hours Western Indonesia Time/GMT+7) $(\mathrm{Neu}$ index/W = 1.19). This finding is rather similar to that of previous research (Fata 2011) which stated that an increase in sumateran tiger activities occurred within the time intervals before dawn until early morning time, day time before late afternoon, and dusk time until before midnight. The period of activity and movement of this sumateran tiger was rather different from that of bengal tigers in Chitwan National Park in Nepal, which were, in general, active and moving, starting at dusk, and before morning time (Sunquist 1981). Schaller (1967) reported that for bengal tigers in India, the most active time was night time, and they took rest, starting in the morning before day time, until late afternoon. However, sometimes tigers hunted during the day time if the animals failed to capture prey animals during the previous night. Sunquist (1981) proved that a tiger's active 
period was closely related to air temperature, and bengal tigers in nepal generally take rest in areas with dense vegetation cover along rivers or streams in day time during summer. Hamilton (1976) reported the same phenomenon, where leopards in Africa were in general not active when air temperature was high during day time. Besides, the pattern of tiger activity is closely related to the active period of its main prey animal (Sunquist 1981; Linkie \& Ridout 2011). The tiger will hunt more easily if its prey animal is highly active, which is from when the sun starts to set until before midnight, and between sunrise and morning time.

\section{Conclusion}

Plantation/regrowth (bush/young secondary forests), lower montane forests, and lowland forests were the vegetation cover types which served as the main habitat for tigers which were translocated to sumatera forest. Areas which were selected as the main habitat for the tigers constituted the dominant natural vegetation cover in the local landscape, where the tigers established their home range. There were found to be no differences in terms of main habitat utilization by the translocated tigers, either in the day time or the night time. Male tigers selected times for activity and hunting of prey animals in the late afternoon until before midnight and at dawn until morning time.

\section{Acknowledgements}

We extend our gratitude and appreciation toward Directorate General of PHKA (Indonesia's Ministry of Forestry), ZSL Indonesia Programme, Forum HarimauKita, Taman Safari Indonesia, Artha Graha Peduli, WCS Indonesia, FFI Indonesia, BPKEL, YLI, PanEco/YEL, Veswic, Australia Zoo, Denver Zoo, Conservation Leadership Program, Idea Wild, and the $10^{\text {th }}$ Duke of Rutland Memorial Conservation Trust for their contribution, support, and cooperation which made this research possible.

\section{References}

Aheams SC, Smith JLD, Joshi AR, Ding J. 2001. TIGMOD, an individual-based spatially explicit model for simulating tiger/human interaction in mutiple use forest. Ecological Modelling 140:81-97. http://dx.doi.org/ 10.1016/S0304-3800(01)00258-7.

Armistead AR, Mitchell K, Connolly GE. 1994. Bear relocation to avoid bear/sheep conflicts. In: Proceedings of the Sixteenth Vertebrate Pest Conference; Lincoln, 16 February 1994. Lincoln: University of Nebraska. pp3135.

Bangs EE et al. 1999. Status of gray wolf restoration in Montana, Idaho, and Wyoming. Wildlife Society Bulletin 26(4):785-798.

Barlow ACD et al. 2011. Female tiger Panthera tigris home range size in the Bangladesh Sundarbans: the value of this mangrove ecosystem for the species' conservation. Oryx 45(1):125-128.
Blanchard BM, Knight RR. 1995. Biological consequences of relocating grizzly bears in the Yellowstone ecosystem. Journal of Wildlife Management 59(3):560-565. http://dx.doi.org/10.2307/3802463.

Begon M, Harper JL, Townsend CR. 1986. Ecology: Individuals, Populations and Communities. Oxford: Blackwell Scientific Publications.

Bibby C, Marsden S, Fielding A. 1988. Bird Habitat Studies. London: The Expedition Advisory Centre, Royal Geographic Society.

Coelho CM et al. 2008. Habitat use by wild maned wolves (Chrysocyon brachyurus) in transition zone environment. Journal of Mammalogy 89(1):97-104. http://dx.doi.org/ 10.1644/06-MAMM-A-383.1.

Edwards GP, de Preu N, Shakeshaft BJ, Crealy IV, Paltridge RM. 2001. Home range and movements of male feral cats (Felis catus) in a semiarid woodland environment in central Australia. Austral Ecology 26:93-101.

Fata I. 2011. Aplikasi SIG untuk analisis distribusi populasi harimau sumatera (Panthera tigris sumatrae, Pocock 1929) dan satwa mangsanya di hutan Blangraweu, kawasan ekosistem Ulu Masen, Aceh [undergraduate thesis]. Bogor: Faculty of Forestry, Bogor Agriculural University.

Franklin N, Bastoni, Siswomartono D, Manansang J, Tilson R. 1999. The Last of the Indonesian Tigers, A Cause for Optimism. In: Seidensticker J, Christie S, Jackson P, editors. Riding the Tiger: Tiger Conservation in a Humandominated Landscape. Cambridge: Cambridge University Press. pp130-147.

Fritts SH, Paul WJ, Mech LD. 1984. Movements of translocated wolves in Minnesota. Journal of Wildlife Management 48(3):709-721. http://dx.doi.org/10. 2307/3801418.

Gamo RS, Rumble MA, Lindzey F, Stefanich M. 2000. GPS radio collar performance as influenced by forest structure and topography. In: Eiler JH, Alcorn DJ, Neuman MR, editors. Biotelemetry 15, Proceedings of the 15th International Symposium on Biotelemetry; Juneau, Alaska USA, May 9-14, 1999. Wageningen: International Society on Biotelemetry. pp464-473.

Goodrich JM, Miquelle DG. 2005. Translocation of problem Amur tigers Panthera tigris altaica to alleviate tiger-human conflicts. Oryx 39(4):454-457. http://dx.doi.org/ 10.1017/S0030605305001146.

Grassman LI, Tewes ME, Silvy NJ, Kreetiyutanont K. 2005. Ecology of three sympatric felids in a mixed evergreen forest in north-central Thailand. Journal of Mammalogy 86(1):29-38. http://dx.doi.org/10.1644/1545-1542(20 05)086<0029:EOTSFI $>2.0 . \mathrm{CO} ; 2$ 
Griffiths M. 1994. Population density of sumatran tigers in the Gunung Leuser National Park. In: Tilson R et al., editors. Sumatran Tiger Population and Habitat Viability Analysis Report. Apple Valley: Indonesian Directorate of Forest Protection and Nature Conservation and IUCN/SSC Conservation Breeding Specialist Group Captive Breeding Specialist Group. pp93-102.

Hamilton PH. 1976. The movements of leopards in Tsavo National Park, Kenya, as determined by radio-tracking [thesis]. Nairobi: University of Nairobi.

Hebblewhite M, Percy M, Merrill EH. 2007. Are all global positioning system collars created equal? Correcting habitat-induced bias using threebrands in the central Canadian Rockies. Journal of Wildlife Management 71(6):2026-2033. http://dx.doi.org/10.2193/2006$\underline{238}$.

Jackson RM. 1996. Home range, movements and habitat use of snow leopard (Uncia uncia) in Nepal [dissertation]. London: University of London.

Karanth KU, Chundawat RS. 2002. Ecology of the tiger: implications for population monitoring. In: Karanth KU, Nichols JD, editors. Monitoring Tigers and Their Prey: A Manual for Researchers, Managers and Conservationists in Tropical Asia. Bangalore: Centre for Wildlife Studies. pp9-21.

Lancia RA, Nichols JD, Pollock KH. 1994. Estimating of number of animals in wildlife populations. In: Bookhoult $\mathrm{T}$, editor. Research and Management Techniques for Wildlife and Habitats. Bethesda: The Wildlife Society. pp215-253.

Linkie M, Ridout MS. 2011. Assessing tiger-prey interactions in Sumatran rainforests. Journal of Zoology 284:224-229.

Maddox T, Priatna D, Gemita E, Salampessy A. 2007. The Conservation of Tigers and Other Wildlife in Oilpalm Plantations. Conservation Report No. 7. London: The Zoological Society of London.

Meittinen J, Shi C, Tan WJ, Liew SC. 2012. 2010 land cover map of insular Southeast Asia in 250-meter spatial resolution. Remote Sensing Letters 3(1):11-20. http://dx.doi.org/10.1080/01431161.2010.526971.

Morris DW. 2003. Toward an ecological synthesis: a case for habitat selection. Oecologia 136:1-13. http://dx.doi. org/10.1007/s00442-003-1241-4. .

Nilsen EB, Pedersen S, Linnell JDC. 2008. Can minimum convex polygon home ranges be used to draw biologically meaningful conclusions? Ecological Research 23(3):635-639. http://dx.doi.org/10.1007/ s11284-007-0421-9.
Nowell K, Jackson P. 1996. Wild Cats: Status Survey and Conservation Action Plan. Gland: IUCN.

Nugraha RT, Sugardjito J. 2009. Assessment and management options for tiger-human conflicts in Kerinci Seblat National Park, Sumatera, Indonesia. Mammal Study 34(3):141-154. http://dx.doi.org/10.3106/041. $\underline{034.0303 .}$.

Priatna D, Santosa Y, Prasetyo LB, Kartono AP. 2012. Home range and movements of male translocated problem tigers in Sumatra. Asian Journal of Conservation Biology 1(1):20-30.

Rabinowitz AR. 1986. Jaguar predation on domestic livestock in Belize. Wildlife Society Bulletin 14(2):170-174.

Rodgers AR, Carr AP, Smith L, Kie JG. 2005. HRT: Home Range Tools for ArcGIS. Ontario: Ontario Ministry of Natural Resources-Centre for Northern Forest Ecosystem Research.

Ruth TK, Logan KA, Sweanor LL, Hornocker MG, Temple LJ. 1998. Evaluating cougar translocation in New Mexico. Journal of Wildlife Management 62(4):1264-1275. http://dx.doi.org/10.2307/3801990.

Sanderson EW et al. 2010. Setting priorities for tiger conservation: 2005-2015. In: Nyhus PJ, Tilson RL, editors. Tigers of the World: The Biology, Politics, and Conservation of Panthera tigris. Second edition. New York: Elsevier/Noyes Publications. pp143-161.

Sankar K et al. 2010. Monitoring of reintroduced tigers in Sariska Tiger Reserve, Western India: Preliminary findings on home range, prey selection and food habits. Tropical Conservation Science 3(3):301-318.

Santosa Y, Rahman DA. 2012. Precision of nest method in estimaing orangutan and determination of important ecologycal factors for management of conservation forest. Journal of Tropical Forest Management. 18(1):39-51.

Schaller GB. 1967. The Deer and the Tiger, A Study of Wildlife in India. Chicago: The University of Chicago Press.

Seidensticker J. 1986. Large carnivores and the consequences of habitat insularization: Ecology and Conservation of Tigers in Indonesia and Bangladesh. In: Miller SD, Everett DD, editors. Cats of the World: Biology, Conservation, and Management. Washington DC: National Wildlife Federation. pp1-41.

Seidensticker J, Lahiri RK, Das KC, Wright A. 1976. Problem tiger in the Sundarbans. Oryx 13(3):267-273. http://dx. doi.org/10.1017/S0030605300013703.

Seidensticker J, Christie S, Jackson P. 1999. Preface. In: Seidensticker J, Christie S, Jackson P, editors. Riding the Tiger: Tiger Conservation in a Human-dominated 
Landscape. Cambridge: Cambridge University Press. ppxv-xix.

Simcharoen S, Barlow ACD, Simcharoen A, Smith JLD. 2008. Home range size and daytime habitat selection of leopards in Huai Kha Khaeng Wildlife Sanctuary, Thailand. Biological Conservation 141(9):2242-2250. http://dx.doi.org/10.1016/j.biocon.2008.06.015.

Smith JLD. 1993. The role of dispersal in structuring the Chitwan tiger population. Behaviour 124(3-4):165-195. http://dx.doi.org/10.1163/156853993X00560.

Stander PE. 1990. A suggested management strategy for stock-raiding lions in Namibia. South African Journal of Wildlife Research 20(2):37-43.

Sunarto. 2011. Ecology and restoration of sumatran tigers in forest and plantation landscapes [dissertation]. Blacksburg: Faculty of Fisheries and Wildlife Sciences, Virginia Polytechnic Institute and State University.

Sunarto S et al. 2012. Tigers need cover: multy-scale occupancy study of the big cat in sumatran forest and plantation landscapes. Plos ONE 7(1):1-14. http://dx. doi.org/10.1371/journal.pone.0030859.

Sunquist ME. 1981. The social organization of tigers (Panthera tigris) in Royal Chitwan National Park, Nepal.
Smithsonian Contributions to Zoology 336:1-98. http://dx.doi.org/10.5479/si.00810282.336.

Sunquist M, Karanth KU, Sunquist F. 1999. Ecology, behaviour and resilience of the tiger and its conservation needs. In: Seidensticker J, Christie S, Jackson P, editors. Riding the Tiger, Tiger Conservation in a Humandominated Landscape. Cambridge: Cambridge University Press. pp5-18.

Valeix M et al. 2010. How key habitat features influence large terrestrial carnivores movement: waterholes and african lions in a semi-arid savanna of north-western Zimbabwe. Landscape Ecology 25:337-351. http://dx.doi.org/10.1007/s10980-009-9425-x.

Wibisono HT, Pusparini W. 2010. Sumatran tiger (Panthera tigris sumatrae): a review of conservation status. Integrative Zoology 5:309-318. http://dx.doi. org/10.1111/j.1749-4877.2010.00219.x.

Xu F et al. 2012. Winter habitat use of snow leopards in Tomur National Nature Reserve of Xinjiang, Northwest China. Journal of Arid Land 4(2):191-195. http://dx.doi.org/10.3724/SP.J.1227.2012.00191.

Zar JH. 1996. Biostatistical Analysis. New Jersey: PrenticeHall International Inc. 